\title{
IoT Based Solar Panel Tracking System with Weather Monitoring System
}

\author{
K. Dinesh ${ }^{\mathrm{a}, 1}$, Lakshmi Priya. A ${ }^{\mathrm{b}}$, Preethi. $\mathrm{T}^{\mathrm{b}}$, Sandhya. $\mathrm{M}^{\mathrm{b}}$, Sangeetha. $\mathrm{P}^{\mathrm{b}}$ \\ a Professor, Department of Electrical and Electronics Engineering \\ ${ }^{b} U G$ Student, Department of Electrical and Electronics Engineering \\ Panimalar Institute of Technology, Chennai,TN, India
}

\begin{abstract}
Solar power is the burgeoning method of continual energy. The assignment is designed and carried out the use of dual axis sun tracker system. In order to maximise power era from solar, it's important to introduce sun ray monitoring systems into solar electricity production. A dual-axis tracker can boom power through monitoring solar rays from switching photovoltaic cells in various directions. These photovoltaic cells can rotate in all directions. The LDR (Light Dependent Resistor) have been used to feel the depth of mild at 30 degree every or at 180 degree general and ship the information to microcontroller. This assignment also can be used to experience rain drop, temperature and humidity using sensor and they may be displayed on LCD. We can save the Solar energy in battery.
\end{abstract}

Keywords. Photovoltaic cells, LDR (Light Dependent Resistor), IOT, Microcontroller ATMEGA 328P, Temperature sensor, Humidity sensor, Rain drop sensor.

\section{Introduction}

Solar trackers are growing in popularity, however now no longer all people know the entire advantages and capability hazards of the framework. Photovoltaic cells tracking following solutions are a prominent predominant innovation for mounting photovoltaic boards [1]. Stationary photovoltaic board, which maintain photovoltaic boards in a constant position, will have their productiveness compromised whilst the solar passes to a less-than-most excellent slant. In order to overcome this, sun trackers robotically pass to "track" the development of the solar throughout the atmosphere, thereby magnify the result. Tracker generate greater energy than their stationary opposite numbers because of elevated direct publicity to sun rays [2]. This increase may be as a great deal as 10 to $25 \%$ pending at the geographic region of the monitoring system. There are many special styles of sun trackers, such a single-axis and dualaxis trackers, all of which may be the perfect healthy for a completely unique jobsite. Installation size, neighborhood climate, diploma of range and electric necessities are all crucial concerns that can impact the form of sun tracker excellent ideal for a selected photovoltaic cells initiation.

\footnotetext{
${ }^{1}$ K. Dinesh, Professor, Department of Electrical and Electronics Engineering Panimalar Institute of Technology, Chennai, TN, India; E-mail:mailforkdinesh@gmail.com.
} 
Solar trackers generate greater energy in kind of the same quantity of area wanted for constant-tilt systems, making them perfect for optimizing of land.

\section{Existing System}

Sun is the crucial supply of power. It is the renewable source of electricity production and it's distant liberated from esteem [3]. Now day's fossil fuels are limited. Fossil gas is high-priced and that they motive plenty of pollutants compared to solar power [4]. As we recognize that solar power is freed from price and does now no longer motive any type of pollutants. To keep away from this disadvantage of fossil gas we use sun power. Solar power is turning into a vital power supply as petroleumprimarily based totally sources grow to be extra expensive. Solar power is now ample and sun generation is developing as increasingly more human beings put sun electricity to work. Previous kind of sun monitoring machine was fixed device [5]. Solar panels which might be utilized in those structures are most effective in a single way direction. And this framework creates moo quality on the yield. As we will see there are numerous troubles that arise withinside the present sun device.

\section{Proposed System}

To overcome these drawbacks of existing system we propose a new Solar tracking system can rotate 180 degree on both horizontal and vertical position of panel which can optimize the solar power generation [6]. This assignment makes use of five sensors in horizontal \& vertical route to experience the route of most depth of luminescence [710]. Its sensor will face 30 degree so the overall perspective that the device can experience is one hundred eighty degree. This device will use pic microcontroller as an important electronic to function this device and motor to rotate the solar batteries. The perspective/route of solar batteries will be exhibited on the LCD. Then LDR sensor detects the solar rays and offers the facts to microcontroller. Then microcontroller compares the depth of luminescence and it offers the command to motor. As steady with the commands motor activities the solar batteries to multiple directions. The output voltage is stored in battery and we can monitor the voltage level in IoT also displayed on the LCD. Controller can also be used to monitor the rain, temperature and humidity present in the air. In Figure 1, Automatically cleaning mechanism for the solar panel is implemented to remove the dust partials present in the surface of panel.

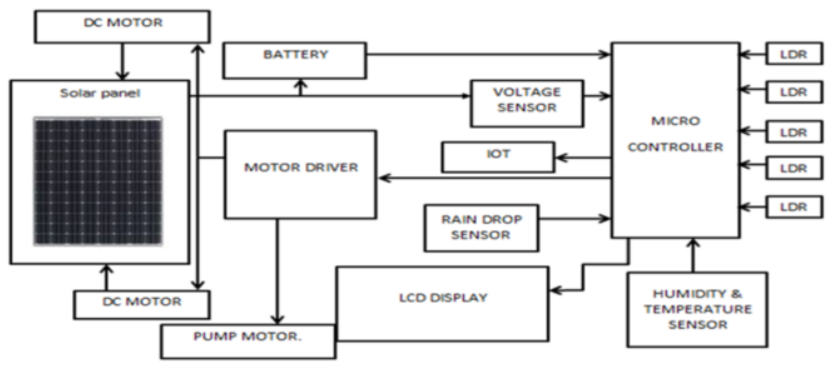

Figure 1. Represents the block diagram of the proposed work 


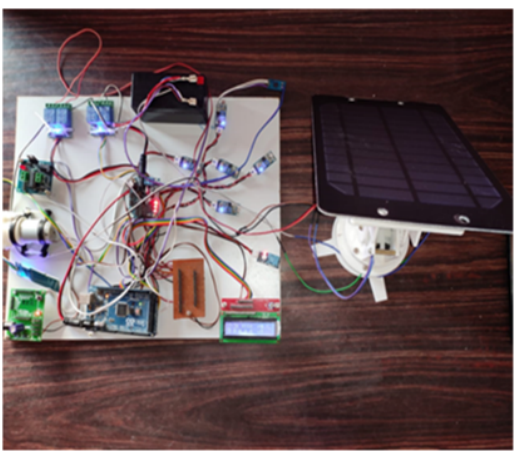

Figure 2. Vertical direction 180 degree

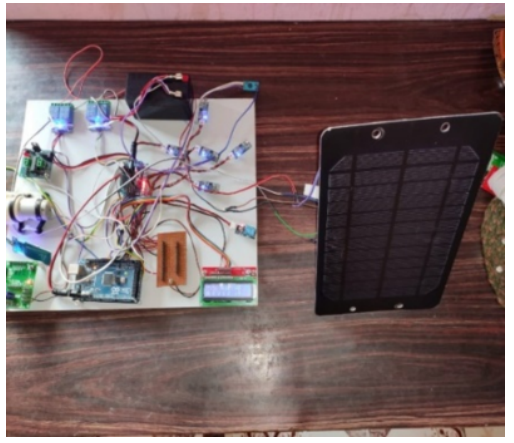

Figure 3. Towards sun ray intensity

Figure 2 and Figure 3, It displays the vertical $180^{\circ}$ direction of the photovoltaic cells respective to the sun ray intensity on the LDR.

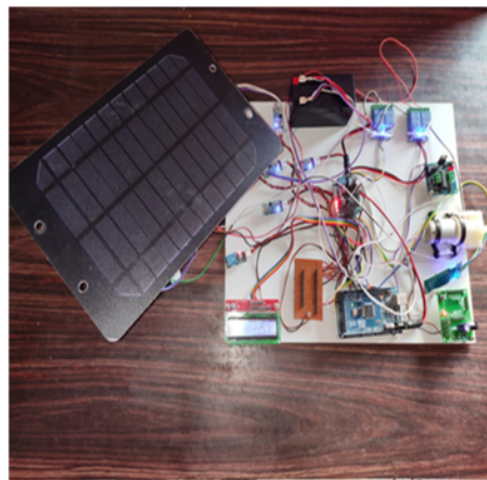

Figure 4. Horizontal 180 degree Direction

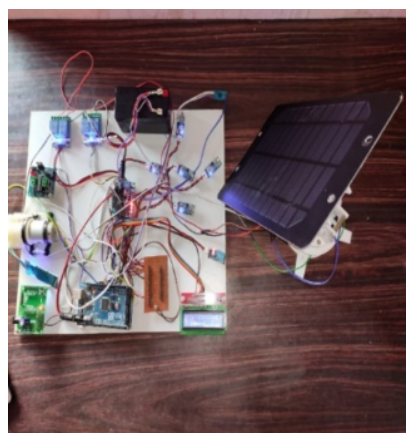

Figure 5. Direction to Sun ray intenstiy

Figure 4 and Figure 5, It shows the horizontal $180^{\circ}$ direction of the photovoltaic cells corresponding to the sun ray intensity on the LDR.

\section{Results and Disscusion}

In this arrangement, the battery initially has $9 \mathrm{~V}$ and provides power to the compnonents in the prototype. The LDR(Light Detetector Sensor) detects the intensity of solar ray in multiple direction and pass on the information to the microcontroller ATmega328P. The ATmega328P detects the highest range of solar ray direction and command the DC motor to change the direction of solar batteries corresponding to the direction.

The power produced from the photovoltaic cells is stored in the battery. Additionally this arrangement consists of humidity sensor, water level sensor, temperature sensor and voltage sensor in Figure 6. These sensor detects the value of temperature, humidity, water level in the atmosphere and the voltage produced by the panel. Figure 7, the resultant value from these sensors are displayed in the IOT server. They are also displayed on the LCD in digital mode. Additionally the prototype also 
consist of pump motor which sprays water and clean the solar panel every 2 minutes in Figure 8 .

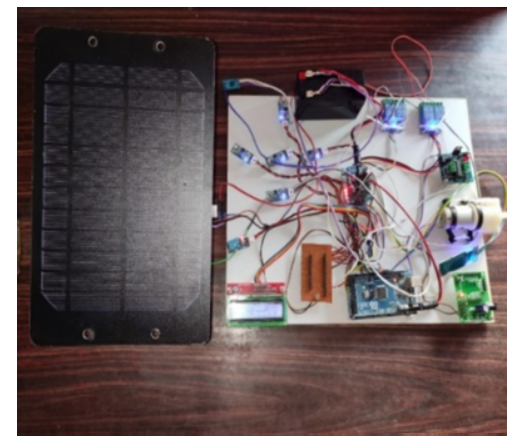

Figure 6. The prototype of developed product

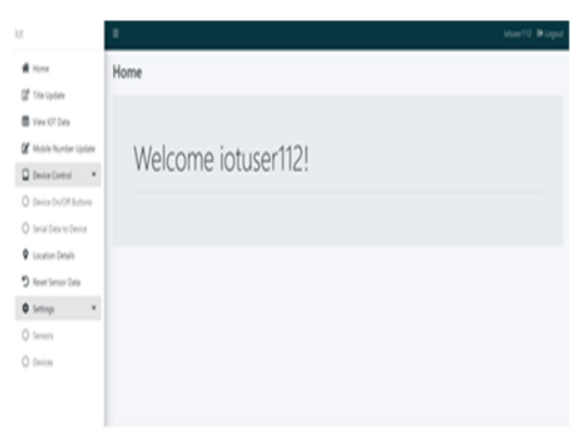

Figure 8. Homepage of IOT application

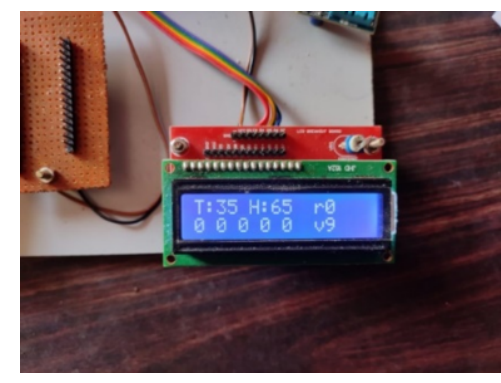

Figure 7. LCD

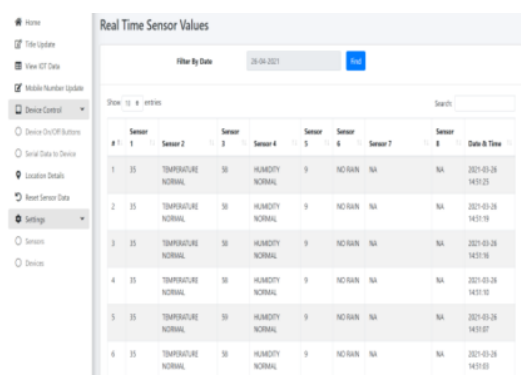

Figure 9. Server page

In Figure 9, the IoT server displays the temperature sensor, humidity sensor and water level sensor in tabular column. The second column shows the value of temperature sensor,the fourth column displays the value of humidity sensor and the sixth column displays the water level sensor count. The server also displays the date and time of the value measured.

\section{Conclusion}

This Created framework can be executed in several solar plant stations to measure the precise strength created from the ones devices. Also, this assignment may be carried out within side the far flung desolate tract areas. Solar tracking system is greater efficient than each other regular solar board. It is feasible to lessen the control catastrophe to many tremendous extent.

\section{References}

[1] Marinescu, D., \& Marinescu, C. (2006). Control Optimizing Algorithm for Soft Sun-Trackers. 2006 IEEE International Conference on Automation, Quality and Testing, Robotics, 1, 54-57. https://doi.org/10.1109/AQTR.2006.254496 
[2] Cotton, M. F., \& Rabie, H. (2015). Maintenance of antiretroviral efficacy in children. The Lancet HIV, 2(4), e120-e121. https://doi.org/10.1016/S2352-3018(15)00040-5

[3] Visconti, P., Ventura, V., Tempesta, F., Romanello, D., \& Cavalera, G. (2011). Electronic system for improvement of solar plant efficiency by optimized algorithm implemented in biaxial solar trackers. 2011 10th International Conference on Environment and Electrical Engineering, 1-4. https://doi.org/10.1109/EEEIC.2011.5874639

[4] Angelkov, D., Koceska, N., \& Koceski, S. (2014). Low-cost dual-axis system for solar tracking. 2014 3rd Mediterranean Conference on Embedded Computing (MECO), 169-172. https://doi.org/10.1109/MECO.2014.6862685

[5] Veligorskyi, O., Kosenko, R., \& Stepenko, S. (2014). High-efficiency solar tracker development and effectiveness estimation. 2014 IEEE International Conference on Intelligent Energy and Power Systems (IEPS), 153-158. https://doi.org/10.1109/IEPS.2014.6874169

[6] Hammad, B. K., Fouad, R. H., Ashhab, M. S., Nijmeh, S. D., Mohsen, M., \& Tamimi, A. (2014). Adaptive control of solar tracking system. IET Science, Measurement \& Technology, 8(6), 426-431. https://doi.org/10.1049/iet-smt.2013.0293

[7] Kulkarni, A., Kshirsagar, T., Laturia, A., \& Ghare, P. H. (2013). An Intelligent Solar Tracker for Photovoltaic Panels. 2013 Texas Instruments India Educators' Conference, 390-393. https://doi.org/10.1109/TIIEC.2013.76

[8] Alqarni, M., \& Darwish, M. K. (2012). Maximum power point tracking for photovoltaic system: Modified Perturb and Observe algorithm. 2012 47th International Universities Power Engineering Conference (UPEC), 1-4. https://doi.org/10.1109/UPEC.2012.6398443

[9] Hinov, N. (2017). New method for designing serial resonant power converters. 060019. https://doi.org/10.1063/1.5014013

[10] Hensel, S., \& Marinov, M. B. (2018). Comparison of Algorithms for Short-term Cloud Coverage Prediction. 2018 IX National Conference with International Participation (ELECTRONICA), 1-4. https://doi.org/10.1109/ELECTRONICA.2018.8439356 D. Marinescu, C. Marinescu. Control Optimizing Algorithm for Soft Sun-Trackers. Automation, Quality and Testing, Robotics, 2006. 